\title{
基于四苯乙烯的四齿唑盐：合成和对离子的选择性识别
}

\author{
李芯颖 †赵志翔†胡林海魏登澈柳清湘* \\ (天津师范大学化学学院 天津市功能分子结构与性能重点实验室 天津 300387)
}

\begin{abstract}
摘要 合成和表征了两种新型的基于四苯基乙烯的四齿唑盐: 1,1,2,2-四 [(2'-( $N$-甲基咪唑-1-基)乙氧基苯基)]乙烯六氟磷 酸盐(1) 和 1,1,2,2-四[(2'-( $N$-吡啶甲基苯并咪唑-1-基)乙氧基苯基)]乙烯六氟磷酸盐(2)通过苂光光谱, $U V / v i s$ 光谱, HRMS, ${ }^{1} \mathrm{H} \mathrm{NMR}$ 和红外光谱研究了 1 对阴离子和 2 对阳离子的识别性能. 结果表明: 通过苂光方法, $\mathbf{1}$ 能够将 $\mathrm{H}_{2} \mathrm{PO}_{4}^{-}$与其他阴 离子区分开, 2 能够将 $\mathrm{Ag}^{+}$与其他阳离子区分开.

关键词 四苯乙烯; 唑盐; 苂光; 识别; 离子
\end{abstract}

\section{Tetraphenylethylene-Based Tetradentate Azolium Salts: Synthesis and Selective Recognition for lons}

\author{
Li, Xinying $^{\dagger} \quad$ Zhao, Zhixiang $^{\dagger} \quad \mathrm{Hu}$, Linhai $\quad$ Wei, Dengche $\quad$ Liu, Qingxiang* \\ (Tianjin Key Laboratory of Structure and Performance for Functional Molecules, College of Chemistry, \\ Tianjin Normal University, Tianjin 300387)
}

\begin{abstract}
Two new tetraphenylethylene-based tetradentate azolium salts, 1,1,2,2-tetrakis $\{[2$ '-( $N$-methyl-imidazolium-1-yl)ethoxyl]phenyl $\}$ ethylene hexafluorophosphate (1) and 1,1,2,2-tetrakis $\left\{\left[2^{\prime}-(N\right.\right.$-picolyl-benzimidazolium-1-yl)ethoxyl $]$ phenyl $\}$ ethylene hexafluorophosphate (2), were synthesized and characterized. Recognitions of $\mathbf{1}$ for anions and $\mathbf{2}$ for cations were studied through fluorescence spectra, UV/vis spectra, HRMS, ${ }^{1} \mathrm{H}$ NMR and infrared spectroscopies. The results revealed that 1 was able to differentiate $\mathrm{H}_{2} \mathrm{PO}_{4}^{-}$from other anions, and $\mathbf{2}$ was able to differentiate $\mathrm{Ag}^{+}$from other cations via fluorescence method.
\end{abstract}

Keywords tetraphenylethylene; azolium salts; fluorescence; recognition; ions

\section{Introduction}

Development of fluorescence probes for ions is of great significance in host-guest chemistry. ${ }^{[1-10]}$ Among the anions, the detection of dihydrogen phosphate plays an important part in the eutrophication of natural water sources. Some fluorescence probes for dihydrogen phosphate have been reported. ${ }^{[1-13]}$ For example, the probes using urea groups or amide groups as binding sites have big association

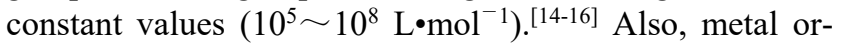
ganic frameworks (MOFs) or triazolium types of probes have good recognition ability for dihydrogen phosphate. ${ }^{[17-18]}$ In addition, silver is an element with bactericidal function. ${ }^{[19-22]}$ The suitable amount of silver ion in human body can kill bacteria, ${ }^{[23-26]}$ but excessive silver ion can lead to insoluble precipitates in skin and eyes. ${ }^{[27]}$ Besides, ex- cessive silver ion can destroy biological system via combining with activated sulfhydryl enzymes and amine groups ${ }^{[28]}$ Recently, several interesting fluorescence probes for silver ion were reported. For example, the probes bearing cucurbit[10]uril or dicyanomethylene- $4 H$-chromene moieties were of obvious color change when silver ion was held. ${ }^{[29-30]}$ Also, a highly selective turn-on-type of probe bearing indole moieties for silver ion was developed by Zhang et al ${ }^{[31]}$ Even so, developing more convenient and effective method of detection for dihydrogen phosphate or silver ion is still desired.

In the process of searching suitable fluorescence probes for dihydrogen phosphate or silver ion, we are interested in tetradentate azolium salts with different substituent groups, because this type of compounds can hold guests via hydrogen bonds, coordinating interactions and so on. In the

\footnotetext{
* Corresponding author. E-mail: tjnulqx@163.com

Received March 5, 2021; revised March 24, 2021; published online July 5, 2021.

Project supported by the Tianjin Natural Science Foundation (No. 18JCZDJC99600), the National Natural Science Foundation of China (No. 21572159) and the Program for Innovative Research Team in University of Tianjin (No. TD13-5074).

天津自然科学基金(No. 18JCZDJC99600)、国家自然科学基金(No. 21572159)和天津师范大学创新研究团队计划(No. TD13-5074)资助项目.

†共同第一作者(These authors contributed equally to this work).
} 
paper, we designed and synthesized two new tetraphenylethylene-based tetradentate azolium salts 1,1,2,2-tetrakis$\left\{\left[2^{\prime}-(N\right.\right.$-methyl-imidazolium-1-yl)ethoxyl $]$ phenyl $\}$ ethylene hexafluorophosphate (1) and 1,1,2,2-tetrakis $\left\{\left[2^{\prime}-(N\right.\right.$-picolyl-benzimidazolium-1-yl)ethoxyl]phenyl ethylene hexafluorophosphate (2). Particularly, selective recognitions of $\mathbf{1}$ for anions and $\mathbf{2}$ for cations were studied through fluorescence spectra, UV/vis spectra, ${ }^{1} \mathrm{H}$ NMR, HRMS and infrared spectra.

\section{Results and discussion}

\subsection{Preparation and characterization of $\mathbf{1}$ and $\mathbf{2}$}

As shown in Scheme 1, 4,4'-dihydroxybenzophenone underwent McMurry coupling reaction to afford 1,1,2,2tetrakis(4-hydroxylphenyl)ethylene, which reacted with 1,2-dibromoethane to give 1,1,2,2-tetrakis[4-(2'-bromoethoxy)phenyl]ethylene. Subsequently, this compound was treated with $N$-methyl-imidazole (or $N$-picolyl-benzimidazole) in $\mathrm{CH}_{3} \mathrm{CN}$ to generate light yellow solid (or white solid). The solids were dissolved in methanol via the anion exchange reaction with ammonium hexafluorophosphate to form 1,1,2,2-tetrakis \{4-[2'-( $N$-methyl-imidazolium-1-yl)ethoxyl]phenyl $\}$ ethylene hexafluorophosphate (1) or 1,1 , 2,2-tetrakis $\left\{\left[2^{\prime}-(N\right.\right.$-picolylbenzimidazolium-1-yl)ethoxyl]phenyl ethylene hexafluorophosphate (2). Compounds 1 and $\mathbf{2}$ are soluble in $N, N$-dimethylformamide (DMF) and dimethyl sulfoxide (DMSO), however, they are difficult to dissolve in ether and alkane solvents. In the ${ }^{1} \mathrm{H}$ NMR spectra of $\mathbf{1}$ and $\mathbf{2}$, the proton signal of azolium (NCHN) appeared at $\delta 9.13$ for $\mathbf{1}$ and $\delta 9.95$ for $\mathbf{2}$, and these two values are analogue to those of imidazolium or benzimidazolium salts reported. ${ }^{[32-33]}$

\subsection{Recognition of compound 1 for $\mathrm{H}_{2} \mathrm{PO}_{4}^{-}$}

The anionic screening experiment $\left(\mathrm{H}_{2} \mathrm{PO}_{4}^{-}, \mathrm{OAc}^{-}\right.$, $\mathrm{HSO}_{4}^{-}, \mathrm{NO}_{3}^{-}, \mathrm{I}^{-}, \mathrm{Br}^{-}, \mathrm{Cl}^{-}$and $\mathrm{F}^{-}$, using $\mathrm{TBA}^{+}$salts) using 1 as a host was conducted at room temperature in EtOH/DMSO $(V: V=99: 1)$ by fluorescence spectra. As illustrated in Figure 1, free $1\left(1 \times 10^{-6} \mathrm{~mol} / \mathrm{L}\right)$ displayed a weak peak of tetraphenylethene in the range of $400 \sim 600$ $\mathrm{nm}\left(\lambda_{\mathrm{ex}}=345 \mathrm{~nm}\right.$, the emission and excitation slit: 5 and 10 $\mathrm{nm})$. The fluorescence emission of $\mathbf{1}$ did not alter obviously when 5.0 equiv. of anions $\left(\mathrm{OAc}^{-}, \mathrm{HSO}_{4}^{-}, \mathrm{NO}_{3}^{-}, \mathrm{I}^{-}, \mathrm{Br}^{-}\right.$, $\mathrm{Cl}^{-}$and $\mathrm{F}^{-}$) were added. Whereas the same amount of $\mathrm{H}_{2} \mathrm{PO}_{4}^{-}$was added, the fluorescence intensity of $\mathbf{1}$ at $400 \sim 600 \mathrm{~nm}$ enhanced significantly (free 1 of 3.5 folds), and the red shift of about $18 \mathrm{~nm}$ was observed at the same time. In UV/vis experiment (Figure $\mathrm{S} 1$ ), adding $\mathrm{H}_{2} \mathrm{PO}_{4}^{-}$to the solution of $\mathbf{1}$, a remarkable increase of absorption in $240 \sim 375 \mathrm{~nm}$ was observed, but the absorption of 1 was not obviously influenced by adding other anions. These results indicate that host 1 can selectively differentiate $\mathrm{H}_{2} \mathrm{PO}_{4}^{-}$ from other anions.
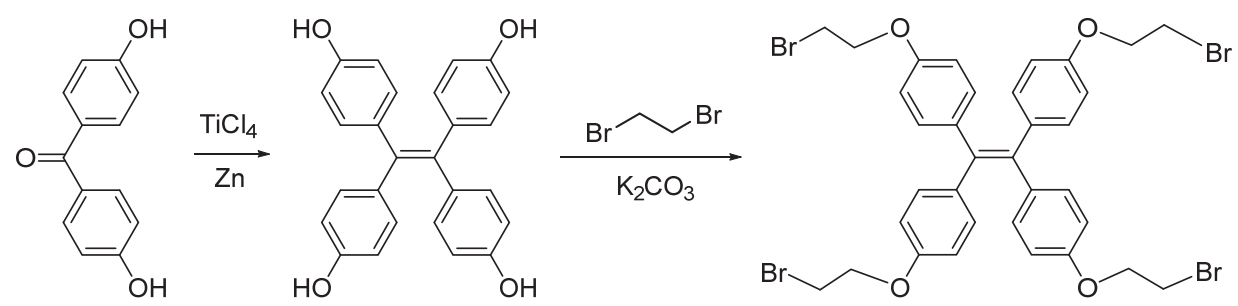

(i) $\stackrel{\mathrm{N}}{-} \mathrm{N}-\mathrm{CH}_{3}$

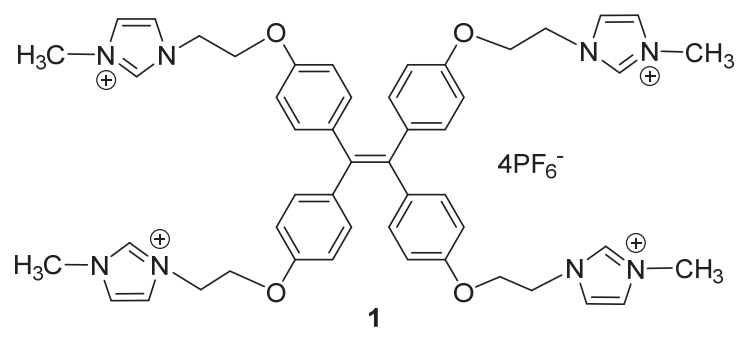

(ii) $\mathrm{NH}_{4} \mathrm{PF}_{6}$

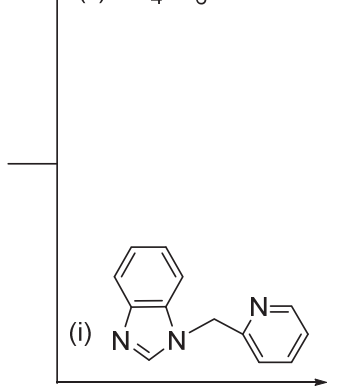

(ii) $\mathrm{NH}_{4} \mathrm{PF}_{6}$

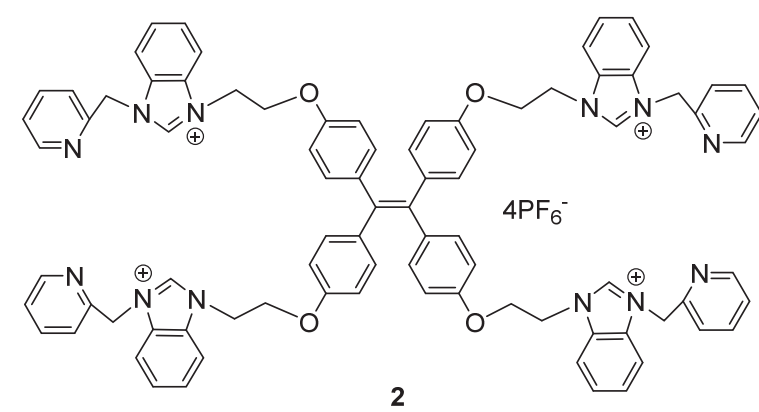

Scheme 1 Preparation of tetradentate azolium salts $\mathbf{1}$ and $\mathbf{2}$ 


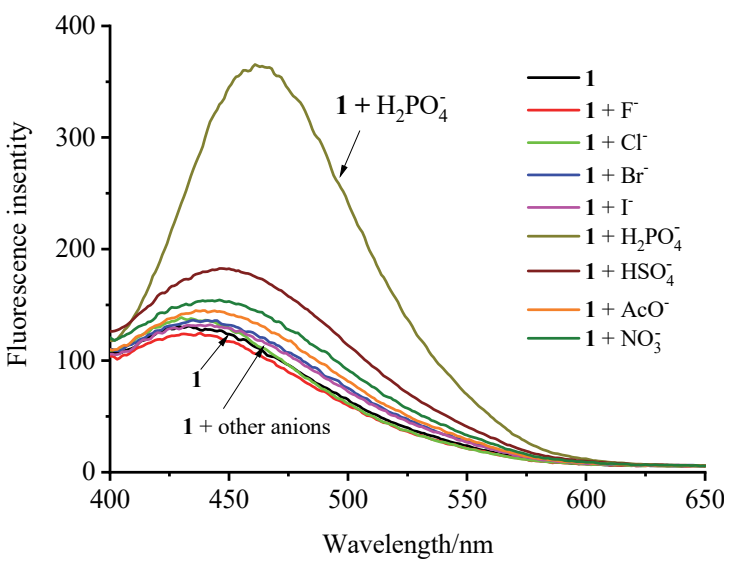

Figure 1 Fluorescent spectra of $\mathbf{1}\left(1 \times 10^{-6} \mathrm{~mol} / \mathrm{L}\right)$ with 5.0 equiv. of $\mathrm{HSO}_{4}^{-}, \mathrm{NO}_{3}^{-}, \mathrm{H}_{2} \mathrm{PO}_{4}^{-}, \mathrm{OAc}^{-}, \mathrm{I}^{-}, \mathrm{F}^{-}, \mathrm{Br}^{-}$and $\mathrm{Cl}^{-}$ in $\mathrm{EtOH} / \mathrm{DMSO}(V: V=99: 1)$ at room temperature

The fluorescence titration experiment was also conducted (Figure 2), where the fluorescence intensity of 1 at $400 \sim$ $600 \mathrm{~nm}$ enhanced gradually with the enhancement of $\mathrm{H}_{2} \mathrm{PO}_{4}^{-}$. When the proportion of $c_{\mathrm{H}_{2} \mathrm{PO}_{4}^{-}} / c_{1}$ did not exceed $1: 1$ (the inset of Figure 2), the fluorescence intensity enhanced quickly with the increase of $c_{\mathrm{H}_{2} \mathrm{PO}_{4}^{-}}$. When the ratio was from $1: 1$ to $5: 1$, the increase of fluorescent intensity slowed down. Upon exceeding $6: 1$, the increase of $c_{\mathrm{H}_{2} \mathrm{PO}_{4}^{-}}$did not cause further enhancement of fluorescence intensity. Through using the linear analysis equation (1), the association constant of $\mathbf{1} \cdot 2 \mathrm{H}_{2} \mathrm{PO}_{4}^{-}$was computed as $K=5.56 \times 10^{11}\left(\mathrm{~mol} \cdot \mathrm{L}^{-1}\right)^{-2}(R=0.997)$, and the binding ratio of 1 and $\mathrm{H}_{2} \mathrm{PO}_{4}^{-}$was $1: 2$ (Figure S2). ${ }^{[34]}$ According to the relationship between the change of fluorescence intensity and $C_{\mathrm{H}_{2} \mathrm{PO}_{4}^{-}}$, the detection limit of $\mathrm{H}_{2} \mathrm{PO}_{4}^{-}$was computed as $1.5 \times 10^{-8} \mathrm{~mol} / \mathrm{L}$ as indicated in Figure $\mathrm{S} 3$, which was relatively lower compared with the values reported in literatures (from $1.1 \times 10^{-5}$ to $1.8 \times 10^{-9} \mathrm{~mol} /$ L). ${ }^{[33,35-38]}$

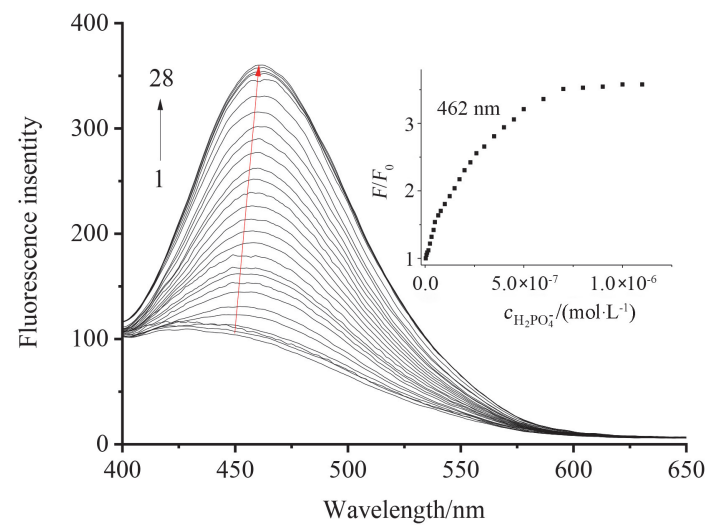

Figure 2 Fluorescent titration of $1\left(1.0 \times 10^{-6} \mathrm{~mol} / \mathrm{L}\right)$ with diverse $c_{\mathrm{H}_{2} \mathrm{PO}_{4}^{-}}$in EtOH/DMSO $(V: V=99: 1)$ at room temperature

$c_{\mathrm{H}_{2} \mathrm{PO}^{-}}$of curves $1 \sim 28$ are $0,0.04,0.07,0.11,0.17,0.25,0.33,0.43$, $0.5,0.67,0.8,1.0,1.25,1.5,1.75,2.0,2.3,2.6,3.0,3.5,4.0,4.5,5.0,6.0$, $7.0,8.0,9.5,11.0 \times 10^{-6} \mathrm{~mol} / \mathrm{L}$ (from bottom to top). Inset: the curve of $F / F_{0}$ vs $c_{\mathrm{H}_{2} \mathrm{PO}_{4}^{-}}$at $400 \sim 600 \mathrm{~nm}$

$$
\frac{\left[c_{1}\right]\left[c_{\mathrm{H}_{2} \mathrm{PO}_{4}^{-}}\right]^{2}}{F-F_{0}}=\frac{1}{\mathrm{a} K}+\frac{\left[c_{\mathrm{H}_{2} \mathrm{PO}_{4}}\right]^{2}}{\mathrm{a}}
$$

in which $F_{0}$ was the fluorescent intensity of pure host, $F$ was the fluorescent intensity of the host with guest, $K$ represented the association constant, $c_{1}$ represented the concentration of host, $c_{\mathrm{H}_{2} \mathrm{PO}_{4}^{-}}$represented the concentration of guest, and a was the constant.

In UV/vis titration experiment (Figure 3), when $\mathrm{H}_{2} \mathrm{PO}_{4}^{-}$ was slowly titrated into the solution of $1\left(1 \times 10^{-5} \mathrm{~mol} / \mathrm{L}\right)$, the absorption peak around $321 \mathrm{~nm}$ enhanced gradually. The stable constant $K_{\mathrm{S}}$ of $1.15 \times 10^{11}\left(\mathrm{~mol} \cdot \mathrm{L}^{-1}\right)^{-2}(R=$ 0.991 ) for $\mathbf{1} \cdot 2 \mathrm{H}_{2} \mathrm{PO}_{4}^{-}$was obtained according to equation (2) (Figure S4), ${ }^{[34]}$ which was analogous to above association constant $K$ obtained by fluorescent titration experiment. As indicated in Job's plot (the inset of Figure 3), when the molar fraction of 1 was 0.67 , the $\chi \Delta I$ value reached maximum, which indicated that $1: 2$ complex stoichiometry ratio for $\mathbf{1} \cdot 2 \mathrm{H}_{2} \mathrm{PO}_{4}^{-}$was established. ${ }^{[39-40]}$

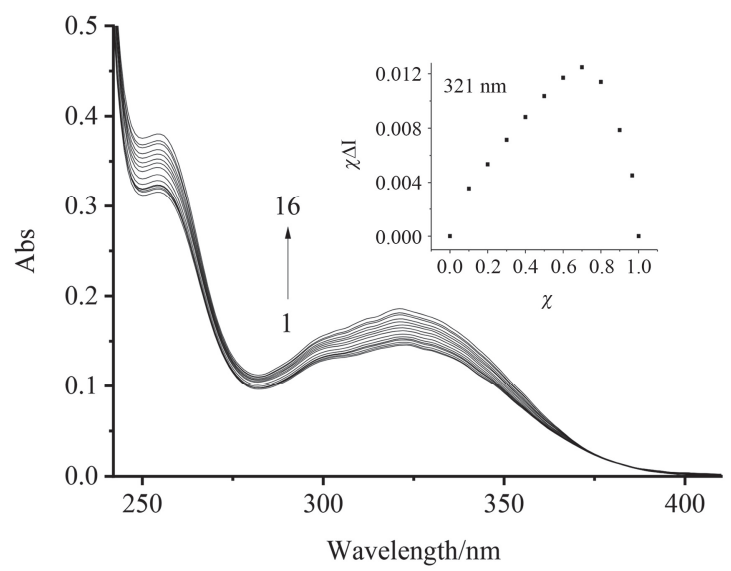

Figure $3 \mathrm{UV} /$ vis titration of $1\left(1.0 \times 10^{-5} \mathrm{~mol} / \mathrm{L}\right)$ with diverse $c_{\mathrm{H}_{2} \mathrm{PO}_{4}^{-}}$in $\mathrm{EtOH} / \mathrm{DMSO}(V: V=99: 1)$ in room temperature $c_{\mathrm{H}_{2} \mathrm{PO}_{4}^{-}}$of curves $1 \sim 16$ are $0,0.03,0.08,0.12,0.19,0.28,0.45,0.69$, $0.8,1.27,1.8,2.75,3.6,4.5,5.5,6.0 \times 10^{-5} \mathrm{~mol} / \mathrm{L}$ (from bottom to top). Inset: Job's plot of $\mathbf{1}^{\bullet} 2 \mathrm{H}_{2} \mathrm{PO}_{4}^{-}$

$$
\frac{\left[c_{1}\right]\left[c_{\mathrm{H}_{2} \mathrm{PO}_{4}^{-}}\right]^{2}}{A-A_{0}}=\frac{1}{\mathrm{a} K_{\mathrm{S}}}+\frac{\left[c_{\mathrm{H}_{2} \mathrm{PO}_{4}^{-}}\right]^{2}}{\mathrm{a}}
$$

where $A_{0}$ was the absorbance of pure host, $A$ was the absorbance of the host with guest, $K_{\mathrm{S}}$ represented the association constant, $c_{1}$ represented the concentration of host, $c_{\mathrm{H}_{2} \mathrm{PO}_{4}^{-}}$represented the concentration of guest, and a was the constant.

To measure the special selective capacity for $\mathrm{H}_{2} \mathrm{PO}_{4}^{-}$, the competition experiments were carried out. Firstly, 5.0 equiv. of various anions $\left(\mathrm{NO}_{3}{ }^{-}, \mathrm{OAc}^{-}, \mathrm{HSO}_{4}^{-}, \mathrm{I}^{-}, \mathrm{Br}^{-}\right.$, $\mathrm{Cl}^{-}$and $\left.\mathrm{F}^{-}\right)$were added to compound $\mathbf{1}\left(1 \times 10^{-6} \mathrm{~mol} / \mathrm{L}\right)$, followed by adding 5.0 equiv. of $\mathrm{H}_{2} \mathrm{PO}_{4}^{-}$. As shown in Figure $\mathrm{S} 5$, no remarkable disturbance was found for $\mathbf{1}$ in the presence of 5.0 equiv. of other anions. Reversible binding experiment for $\mathbf{1}$ and $\mathrm{H}_{2} \mathrm{PO}_{4}^{-}$was conducted as displayed 
in Figure S6. Adding 5.0 equiv. of $\mathrm{Ag}^{+}$into a mixed solution of $1\left(1.0 \times 10^{-6} \mathrm{~mol} / \mathrm{L}\right)$ and $\mathrm{H}_{2} \mathrm{PO}_{4}^{-}\left(2.0 \times 10^{-6}\right.$ $\mathrm{mol} / \mathrm{L}$ ) led to the decrease of fluorescence intensity at $400 \sim$ $600 \mathrm{~nm}$, which was analogous to that of free 1. This result indicated that 1 was regenerated. When $\mathrm{H}_{2} \mathrm{PO}_{4}^{-}$was added again, the fluorescence intensity also increased again. These results showed that $\mathbf{1}$ was an effective sensor for $\mathrm{H}_{2} \mathrm{PO}_{4}^{-}$with satisfactory ability of regeneration and reversibility.

\subsection{Interactions of 1 with $\mathrm{H}_{2} \mathrm{PO}_{4}$}

As observed from the structure of $\mathbf{1}$, the hydrogen atom, oxygen atom and $\pi$ system were the likely binding sites for $\mathrm{H}_{2} \mathrm{PO}_{4}^{-}$. To understand the binding mode of $\mathbf{1}$ with $\mathrm{H}_{2} \mathrm{PO}_{4}^{-},{ }^{1} \mathrm{H}$ NMR titration was conducted in DMSO- $d_{6}$. The spectral differences were displayed in Figure 4. When 2.0 equiv. of $\mathrm{H}_{2} \mathrm{PO}_{4}^{-}$was added (Figure 4(viii)), the signals of $\mathrm{H}_{\mathrm{a}} \sim \mathrm{H}_{\mathrm{e}}$ moved $\delta 0.02 \sim 0.03$ to downfield, while the signals of other protons have no observable change. These indicated that $\mathrm{H}_{2} \mathrm{PO}_{4}^{-}$was held by the hydrogen atoms of imidazole (NCHN) through $\mathrm{C}-\mathrm{H} \cdots \mathrm{O}$ hydrogen bonds as displayed in Scheme 2. Whereas other binding sites (such as oxygen atom and $\pi$ system) did not participate in combining with $\mathrm{H}_{2} \mathrm{PO}_{4}^{-}$, otherwise, the chemical shifts of the protons around oxygen atom or $\pi$ system will change. If the mode of interactions between 1 and $\mathrm{H}_{2} \mathrm{PO}_{4}^{-}$is intermolecular chain-like or layered structure (Scheme S1), the change of proton signals for $\mathbf{1}$ is similar to the case of Scheme 2. Additionally, the signals of $\mathrm{H}_{\mathrm{a}} \sim \mathrm{H}_{\mathrm{e}}$ have no obvious change when adding more $\mathrm{H}_{2} \mathrm{PO}_{4}^{-}$(Figure 4(ix)), which displayed that $1: 2$ complexes between 1 and $\mathrm{H}_{2} \mathrm{PO}_{4}^{-}$were formed. In high resolution mass spectrum of $\mathbf{1} \cdot 2 \mathrm{H}_{2} \mathrm{PO}_{4}^{-}$ (Figure S7), $m / z 513.6259$ for $\left[\left(\mathbf{1}-4 \mathrm{PF}_{6}^{-}+2 \mathrm{H}_{2} \mathrm{PO}_{4}^{-}\right)^{2+} / 2\right]$ was found, which supplied further evidence for formation of $1: 2$ complex between 1 and $\mathrm{H}_{2} \mathrm{PO}_{4}^{-}$.
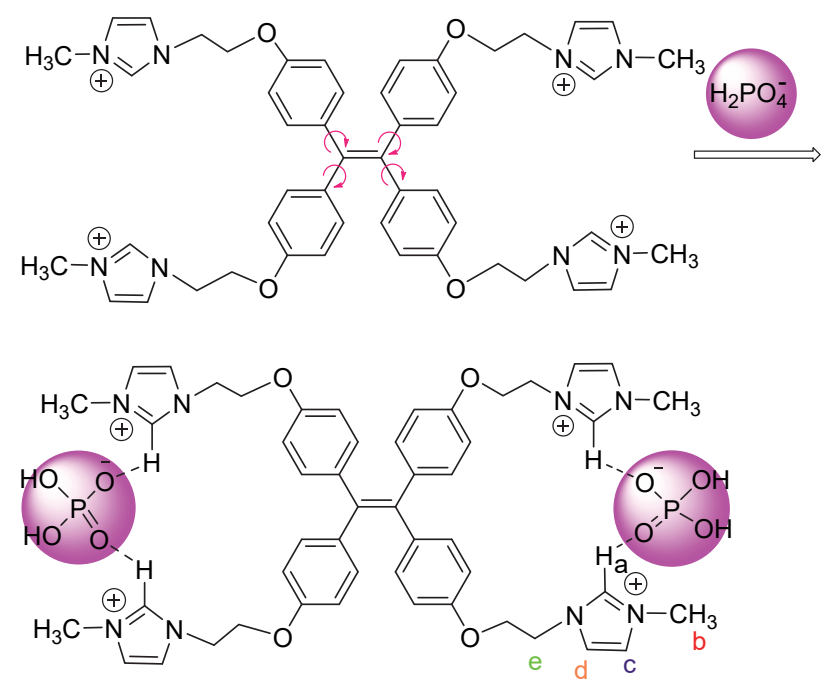

Scheme 2 Intramolecular binding mode of 1 with $\mathrm{H}_{2} \mathrm{PO}_{4}^{-}$

Through comprehensive evaluation of the structure of $\mathbf{1}$, ${ }^{1} \mathrm{H}$ NMR spectra, HRMS and IR for $\mathbf{1}$ and $\mathbf{1} \cdot 2 \mathrm{H}_{2} \mathrm{PO}_{4}^{-}$, the bonding force between 1 and $\mathrm{H}_{2} \mathrm{PO}_{4}^{-}$mainly come from
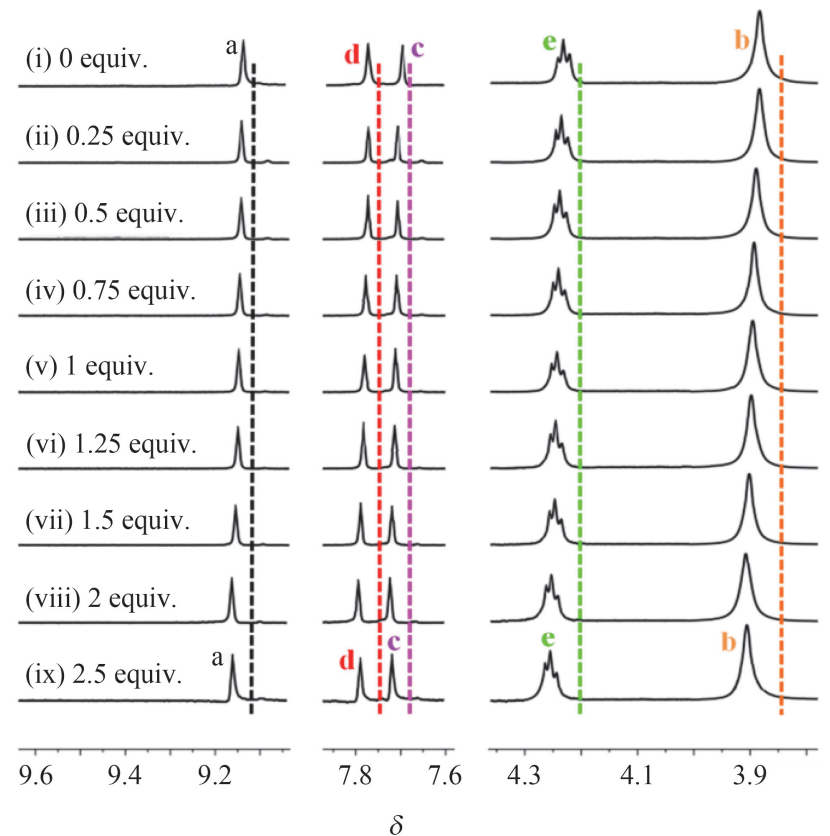

Figure 4 Fractional ${ }^{1} \mathrm{H}$ NMR spectra using DMSO- $d_{6}$ as solvent

(i) Pure 1; (ii) 0.25 equiv. of $\mathrm{H}_{2} \mathrm{PO}_{4}^{-}$and 1; (iii) 0.5 equiv. of $\mathrm{H}_{2} \mathrm{PO}_{4}^{-}$and 1 ; (iv) 0.75 equiv. of $\mathrm{H}_{2} \mathrm{PO}_{4}^{-}$and 1 ; (v) 1.0 equiv. of $\mathrm{H}_{2} \mathrm{PO}_{4}^{-}$and $\mathbf{1}$; (vi) 1.25 equiv. of $\mathrm{H}_{2} \mathrm{PO}_{4}^{-}$and $\mathbf{1}$; (vii) 1.5 equiv. of $\mathrm{H}_{2} \mathrm{PO}_{4}^{-}$and 1 ; (viii) 2.0 equiv. of $\mathrm{H}_{2} \mathrm{PO}_{4}^{-}$and 1 ; (ix) 2.5 equiv. of $\mathrm{H}_{2} \mathrm{PO}_{4}^{-}$and 1

\section{$\mathrm{C}-\mathrm{H} \cdots \mathrm{O}$ hydrogen bonds.}

Infrared spectra for $\mathbf{1}, \mathrm{H}_{2} \mathrm{PO}_{4}^{-}$and $\mathbf{1} \cdot 2 \mathrm{H}_{2} \mathrm{PO}_{4}^{-}$were measured (Figure S8), in which the absorption band of $v\left(\mathrm{C}=\mathrm{N}\right.$ ) shifted from $1603 \mathrm{~cm}^{-1}$ (for 1) to $1615 \mathrm{~cm}^{-1}$ (for $\left.1 \cdot 2 \mathrm{H}_{2} \mathrm{PO}_{4}^{-}\right)$, the absorption band of $v(\mathrm{C}-\mathrm{N})$ shifted from $1242 \mathrm{~cm}^{-1}$ (for 1) to $1232 \mathrm{~cm}^{-1}$ (for $\mathbf{1} \cdot 2 \mathrm{H}_{2} \mathrm{PO}_{4}^{-}$), the absorption band of $v\left(\mathrm{C}-\mathrm{H}\right.$ ) shifted from $830 \mathrm{~cm}^{-1}$ (for 1 ) to $840 \mathrm{~cm}^{-1}$ (for $1 \cdot 2 \mathrm{H}_{2} \mathrm{PO}_{4}^{-}$). The absorption band of $v(\mathrm{P}-$ O) shifted from $1109 \mathrm{~cm}^{-1}$ (for $\mathrm{H}_{2} \mathrm{PO}_{4}^{-}$) to $1129 \mathrm{~cm}^{-1}$ (for $\left.1 \cdot 2 \mathrm{H}_{2} \mathrm{PO}_{4}^{-}\right)$, the absorption band of $v(\mathrm{P}=\mathrm{O})$ shifted from $1248 \mathrm{~cm}^{-1}$ (for $\mathrm{H}_{2} \mathrm{PO}_{4}^{-}$) to $1289 \mathrm{~cm}^{-1}$ (for $\mathbf{1} \cdot 2 \mathrm{H}_{2} \mathrm{PO}_{4}^{-}$).

\subsection{Recognition of 2 for $\mathrm{Ag}^{+}$}

Screening experiment for cations $\left(\mathrm{NH}_{4}^{+}, \mathrm{Na}^{+}, \mathrm{Li}^{+}, \mathrm{Ag}^{+}\right.$, $\mathrm{K}^{+}, \mathrm{Ni}^{2+}, \mathrm{Co}^{2^{+}}, \mathrm{Ca}^{2^{+}}, \mathrm{Cd}^{2+}, \mathrm{Zn}^{2+}, \mathrm{Cu}^{2+}, \mathrm{Pb}^{2+}, \mathrm{Al}^{3^{+}}$and $\mathrm{Cr}^{3+}$, the anions being $\left.\mathrm{NO}_{3}^{-}\right)$using 2 as a host was conducted in EtOH/DMSO $(V: V=99: 1)$ at room temperature. As indicated in Figure 5, a weak peak for free 2 at $400 \sim 600 \mathrm{~nm}$ should be originated from the emission of tetraphenylethene $\left(1.0 \times 10^{-6} \mathrm{~mol} / \mathrm{L}, \lambda_{\mathrm{ex}}=345 \mathrm{~nm}\right.$, emission and excitation slits: 5 and $10 \mathrm{~nm}$ ). Upon adding 30.0 equiv. of cations $\left(\mathrm{Na}^{+}, \mathrm{NH}_{4}{ }^{+}, \mathrm{Li}^{+}, \mathrm{K}^{+}, \mathrm{Ca}^{2+}, \mathrm{Co}^{2+}, \mathrm{Cd}^{2+}\right.$, $\mathrm{Ni}^{2+}, \mathrm{Cu}^{2+}, \mathrm{Pb}^{2+}, \mathrm{Zn}^{2+}, \mathrm{Al}^{3+}$ and $\mathrm{Cr}^{3^{+}}$), no significant change of fluorescence was observed. Whereas the same amount of $\mathrm{Ag}^{+}$was added, the peak at $400 \sim 600 \mathrm{~nm}$ was significantly increased (free 2 of 12 folds). In UV/vis spectra (Figure S9), when the cations were added to the solution of 2 , only $\mathrm{Ag}^{+}$can cause a remarkable increase of the absorption of $\mathbf{2}$ at $250 \sim 320 \mathrm{~nm}$. These results indicated that compound 2 can selectively recognize $\mathrm{Ag}^{+}$. 


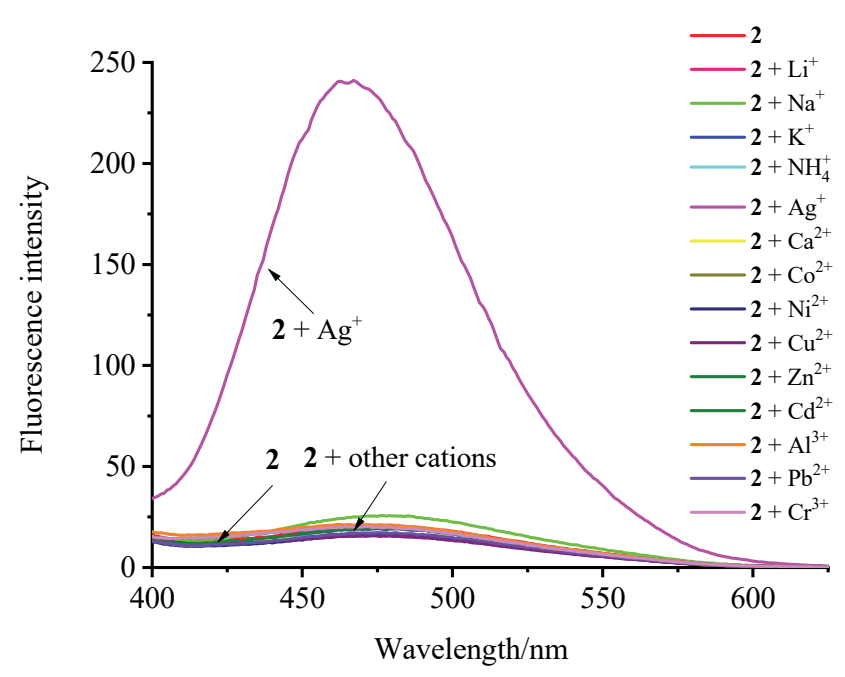

Figure 5 Fluorescence spectra for $2\left(1.0 \times 10^{-6} \mathrm{~mol} / \mathrm{L}\right)$ with salts (30.0 equiv.) of $\mathrm{Ag}^{+}, \mathrm{Na}^{+}, \mathrm{NH}_{4}^{+}, \mathrm{Li}^{+}, \mathrm{K}^{+}, \mathrm{Ca}^{2+}, \mathrm{Co}^{2+}, \mathrm{Cd}^{2+}$, $\mathrm{Ni}^{2+}, \mathrm{Cu}^{2+}, \mathrm{Pb}^{2+}, \mathrm{Zn}^{2+}, \mathrm{Al}^{3+}$ and $\mathrm{Cr}^{3^{+}}$in EtOH/DMSO $(V: V=$ $99: 1)$ at $400 \sim 600 \mathrm{~nm}$ in room temperature

In the fluorescence titration experiment (Figure 6), the fluorescence intensity of 2 at $400 \sim 600 \mathrm{~nm}$ gradually enhanced with increase of $c_{\mathrm{Ag}^{+}}$. As indicated in the inset of Figure 6 , when the ratio of $c_{\mathrm{Ag}^{+}}+c_{2}$ did not exceed $4: 1$, the fluorescence intensity quickly enhanced with the increase of $c_{\mathrm{Ag}^{+}}$. When the ratio was from $4: 1$ to $20: 1$, the increase trend of fluorescence intensity slowed down. When the ratio of $c_{\mathrm{Ag}^{+}} / c_{2}$ exceeded $20: 1$, the fluorescence intensity would not change with the increase of $c_{\mathrm{Ag}^{+}}$. Through using the linear analysis equation (Figure S10), ${ }^{[34]}$ the association constant $K^{\prime}$ of $\mathbf{2} \cdot 2 \mathrm{Ag}^{+}$was calculated as $8.04 \times 10^{10}$ $\left(\mathrm{mol} \cdot \mathrm{L}^{-1}\right)^{-2}(R=0.992)$, and the binding ratio of 2 and $\mathrm{Ag}^{+}$ was $1: 2$. Based on the relationship between fluorescence intensity and $c_{\mathrm{Ag}^{+}}$, the detection limit was calculated as $1.3 \times 10^{-8} \mathrm{~mol} / \mathrm{L}$ (Figure S11), which was lower than known values in the literatures (from $4.1 \times 10^{-6}$ to $8.74 \times$ $\left.10^{-7} \mathrm{~mol} / \mathrm{L}\right){ }^{[41-44]}$

In ultraviolet titration (Figure 7), the absorption band around $240 \sim 360 \mathrm{~nm}$ gradually enhanced upon adding $\mathrm{Ag}^{+}$ to the solution of $2\left(1.0 \times 10^{-6} \mathrm{~mol} / \mathrm{L}\right)$. The stability constant $K^{\prime}$ of $1.42 \times 10^{10}\left(\mathrm{~mol} \cdot \mathrm{L}^{-1}\right)^{-2}(R=0.994)$ for $2 \cdot 2 \mathrm{Ag}^{+}$ was obtained as shown in Figure S12, ${ }^{[28]}$ which was analogous to $K^{\prime}$ from fluorescent method.

To further study the specific selectivity of $\mathbf{2}$ to $\mathrm{Ag}^{+}$, the competition experiment was carried out. Firstly, 30.0 equiv. of various cations $\left(\mathrm{Na}^{+}, \mathrm{NH}_{4}{ }^{+}, \mathrm{Li}^{+}, \mathrm{K}^{+}, \mathrm{Ca}^{2+}, \mathrm{Co}^{2+}, \mathrm{Cd}^{2+}\right.$, $\mathrm{Ni}^{2+}, \mathrm{Cu}^{2+}, \mathrm{Pb}^{2+}, \mathrm{Zn}^{2+}, \mathrm{Al}^{3+}$ and $\left.\mathrm{Cr}^{3^{+}}\right)$was added to the solution of $2\left(1.0 \times 10^{-6} \mathrm{~mol} / \mathrm{L}\right)$, followed by adding 30.0 equiv. of $\mathrm{Ag}^{+}$. Competition event was monitored through fluorescence spectra. As signified in Figure S13, no significant interference was observed for $\mathbf{2}$ when there existed 30.0 equiv. of other various cations. To understand the influence of counterions, other sliver(I) salts ( $\mathrm{AgOAc}$, $\mathrm{AgClO}_{4}, \mathrm{AgPF}_{6}, \mathrm{Ag}_{2} \mathrm{SO}_{4}$ ) were experimented (Figure S14). Upon adding 30.0 equiv. of other silver(I) salts (15.0 equiv. for $\mathrm{Ag}_{2} \mathrm{SO}_{4}$ ), a similar fluorescence response was observed

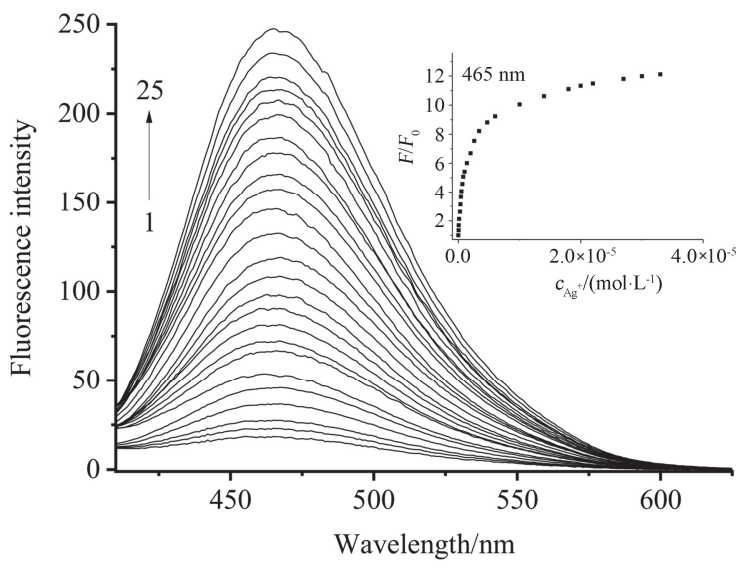

Figure 6 Fluorescence titration for $2\left(1.0 \times 10^{-6} \mathrm{~mol} / \mathrm{L}\right)$ with different $c_{\mathrm{Ag}^{+}}$in EtOH/DMSO $(V: V=99: 1)$ at $400 \sim 600 \mathrm{~nm}$ in room temperature

$c_{\mathrm{Ag}}{ }^{+}$of curves $1 \sim 25$ are $0,0.02,0.07,0.13,0.2,0.28,0.36,0.45,0.65$, $0.8,1.1,1.4,2.0,2.6,3.0,4.0,6.0,10.0,14.0,18.0,20.0,22.0,27.0,30$,

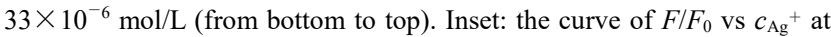
$465 \mathrm{~nm}$

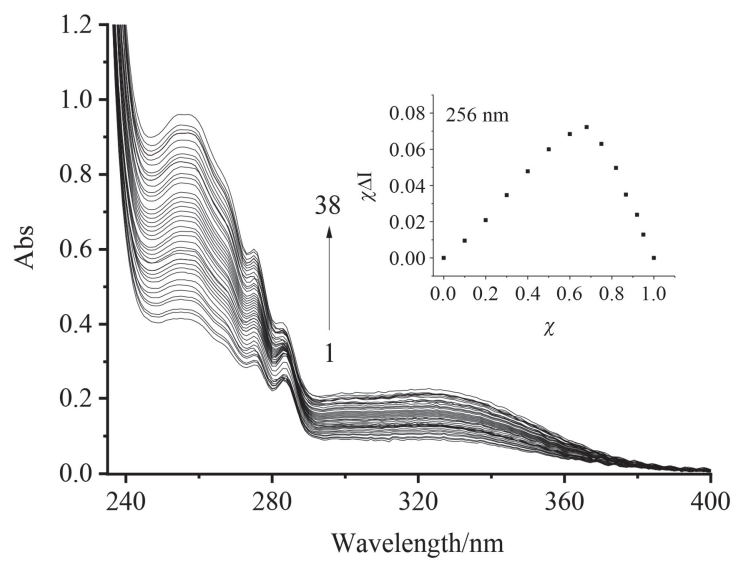

Figure 7 Ultraviolet spectra for $2\left(1.0 \times 10^{-6} \mathrm{~mol} / \mathrm{L}\right)$ with different $c_{\mathrm{Ag}^{+}}$in EtOH/DMSO $(V: V=99: 1)$ in room temperature $c_{\mathrm{Ag}}{ }^{+}$for curves $1 \sim 38$ are $0,0.04,0.07,0.11,0.17,0.25,0.33,0.43,0.5$, $0.6,0.8,1.0,1.2,1.5,1.7,2.3,3,4,5,7,9,10,13,17,20,23,27,30,33$, $36,39,42,45,50,55,60,65$ and $70 \times 10^{-6} \mathrm{~mol} / \mathrm{L}$ (from bottom to top). Inset: Job's plot for $\mathbf{2} \cdot 2 \mathrm{Ag}^{+}$

through comparing with adding the same amount of Ag$\mathrm{NO}_{3}$. This result showed that the counterions have no obvious influence on the recognition of $\mathrm{Ag}^{+}$. Reversible binding of 2 to $\mathrm{Ag}^{+}$was also carried out (Figure S15). Adding 15.0 equiv. of $\mathrm{Na}_{2} \mathrm{~S}$ into the mixed solution of 2 $\left(1.0 \times 10^{-6} \mathrm{~mol} / \mathrm{L}\right)$ and $\mathrm{Ag}^{+}\left(2.0 \times 10^{-6} \mathrm{~mol} / \mathrm{L}\right)$ caused the decrease of fluorescence intensity at $400 \sim 600 \mathrm{~nm}$, and this intensity was analogous to that of free 2. $\mathrm{After}^{+} \mathrm{Ag}^{+}$was added again, the fluorescence intensity increased again. These indicated that 2 was an effective sensor for $\mathrm{Ag}^{+}$with good reversibility and reborn capability.

\subsection{Interaction of $\mathbf{2}$ with $\mathrm{Ag}$}

In host $\mathbf{2}$, the nitrogen atom, oxygen atom and $\pi$ system were the probable binding sites for $\mathrm{Ag}^{+}$. To acquire specific information about the binding mode between 2 and $\mathrm{Ag}^{+},{ }^{1} \mathrm{H}$ NMR titration experiments were carried out in DMSO- $d_{6}$ 
(Figure 8). Upon adding 2 equiv. of $\mathrm{Ag}^{+}$(Figure 8(ix)), the signals of $\mathrm{H}_{\mathrm{a}}$ and $\mathrm{H}_{\mathrm{c}}$ moved $\delta c a .0 .02$ to downfield, the signals of $\mathrm{H}_{\mathrm{b}}, \mathrm{H}_{\mathrm{d}}$ and $\mathrm{H}_{\mathrm{e}}$ moved $\delta 0.02 \sim 0.03$ to highfield, and the signals of other protons did not have observable change. These displayed that there existed $\mathrm{Ag}^{+} \cdots \mathrm{N}$ interactions between 2 and $\mathrm{Ag}^{+}$(Scheme 3). Whereas other binding sites (such as oxygen atom and $\pi$ system) did not participate in combining with $\mathrm{Ag}^{+}$, otherwise, the chemical shifts of the protons around oxygen atom or $\pi$ system will change. If the mode of interactions between 2 and $\mathrm{Ag}^{+}$was intermolecular chain-like or layered structure (Scheme S1), the change of proton signals for $\mathbf{2}$ was similar to the case of Scheme 3. Besides, the signals of $\mathrm{H}_{\mathrm{a}} \sim \mathrm{H}_{\mathrm{e}}$ did not change observably with further addition of $\mathrm{Ag}^{+}$(Figure 8(x)), indicating that a $1: 2$ complex was formed between 2 and

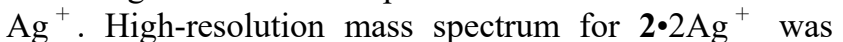
measured as indicated in Figure S16, in which 259.1362 $\left[\left(2-4 \mathrm{PF}_{6}{ }^{-}+2 \mathrm{Ag}^{+}\right)^{6+} / 6\right]$ for $2 \cdot 2 \mathrm{Ag}^{+}$was found, which supplied further evidence for the formation of $1: 2$ complex between 2 and $\mathrm{Ag}^{+}$. Additionally, infrared spectra for $\mathbf{2}$ and $\mathbf{2} \cdot 2 \mathrm{Ag}^{+}$were measured (Figure S17), where $v(\mathrm{C}=\mathrm{N}$ ) absorption bands shifted from $1603 \mathrm{~cm}^{-1}$ for 2 to 1615 $\mathrm{cm}^{-1}$ for $2 \cdot \mathrm{Ag}^{+}, v(\mathrm{C}-\mathrm{N})$ absorption bands shifted from $1239 \mathrm{~cm}^{-1}$ for 2 to $1174 \mathrm{~cm}^{-1}$ for $\mathbf{2} \cdot 2 \mathrm{Ag}^{+}$, and $v(\mathrm{C}-\mathrm{H})$ absorption bands shifted from $840 \mathrm{~cm}^{-1}$ for 2 to $851 \mathrm{~cm}^{-1}$ for $2 \cdot 2 \mathrm{Ag}^{+}$.

Through comprehensive evaluation of the structure of $\mathbf{2}$, ${ }^{1} \mathrm{H}$ NMR, HRMS and IR spectra of 2 and $2 \cdot 2 \mathrm{Ag}^{+}$, the binding force of 2 with $\mathrm{Ag}^{+}$mainly come from $\mathrm{Ag}^{+} \cdots \mathrm{N}$ interactions.

\section{Conclusions}

In summary, two tetraphenylethylene-based tetradentate

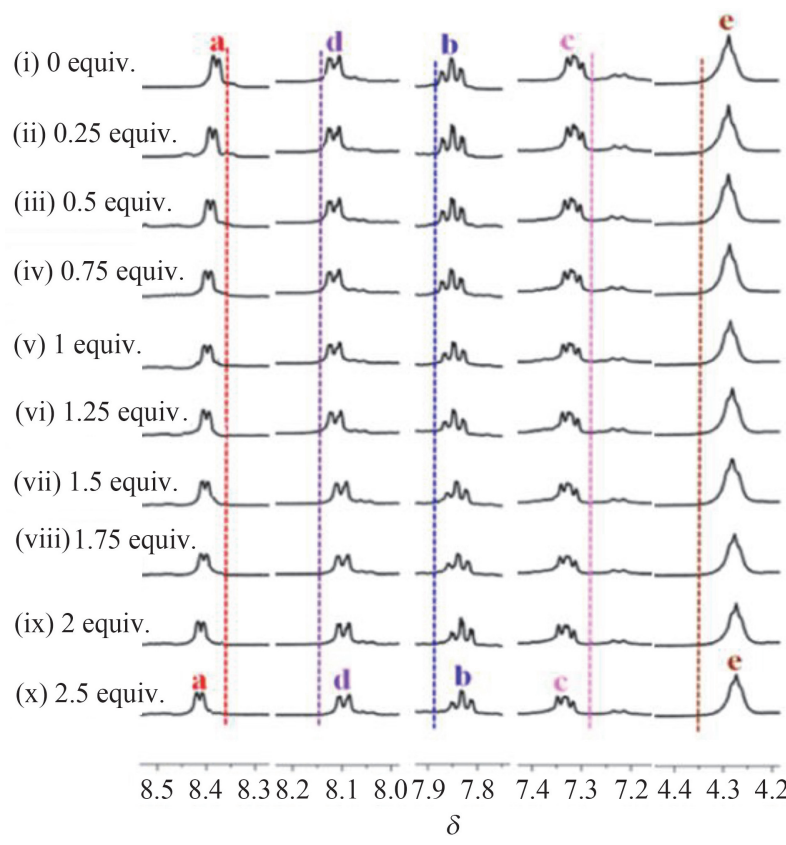

Figure 8 Fractional ${ }^{1} \mathrm{H}$ NMR spectra using DMSO- $d_{6}$ as solvent

(i) 2; (ii) adding 0.25 equiv. of $\mathrm{Ag}^{+}$to 2; (iii) adding 0.5 equiv. of $\mathrm{Ag}^{+}$to 2; (iv) adding 0.75 equiv. of $\mathrm{Ag}^{+}$to 2 ; (v) adding 1.0 equiv. of $\mathrm{Ag}^{+}$to 2 ;

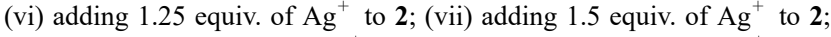
(viii) adding 1.75 equiv. of $\mathrm{Ag}^{+}$to 2 ; (ix) adding 2.0 equiv. $\mathrm{of}^{+}$to 2 ; (x) adding 2.5 equiv. of $\mathrm{Ag}^{+}$to 2

azolium salts $\mathbf{1}$ and $\mathbf{2}$ have been synthesized and characterized. Main structural differences of $\mathbf{1}$ and $\mathbf{2}$ were in the side chains ( $(N$-methyl-imidazolium-1-yl)ethoxyl for $\mathbf{1}$ and ( $N$-picolyl-benzimidazolium-1-yl)ethoxyl for 2). Therefore, they contained different binding sites for guests. In the

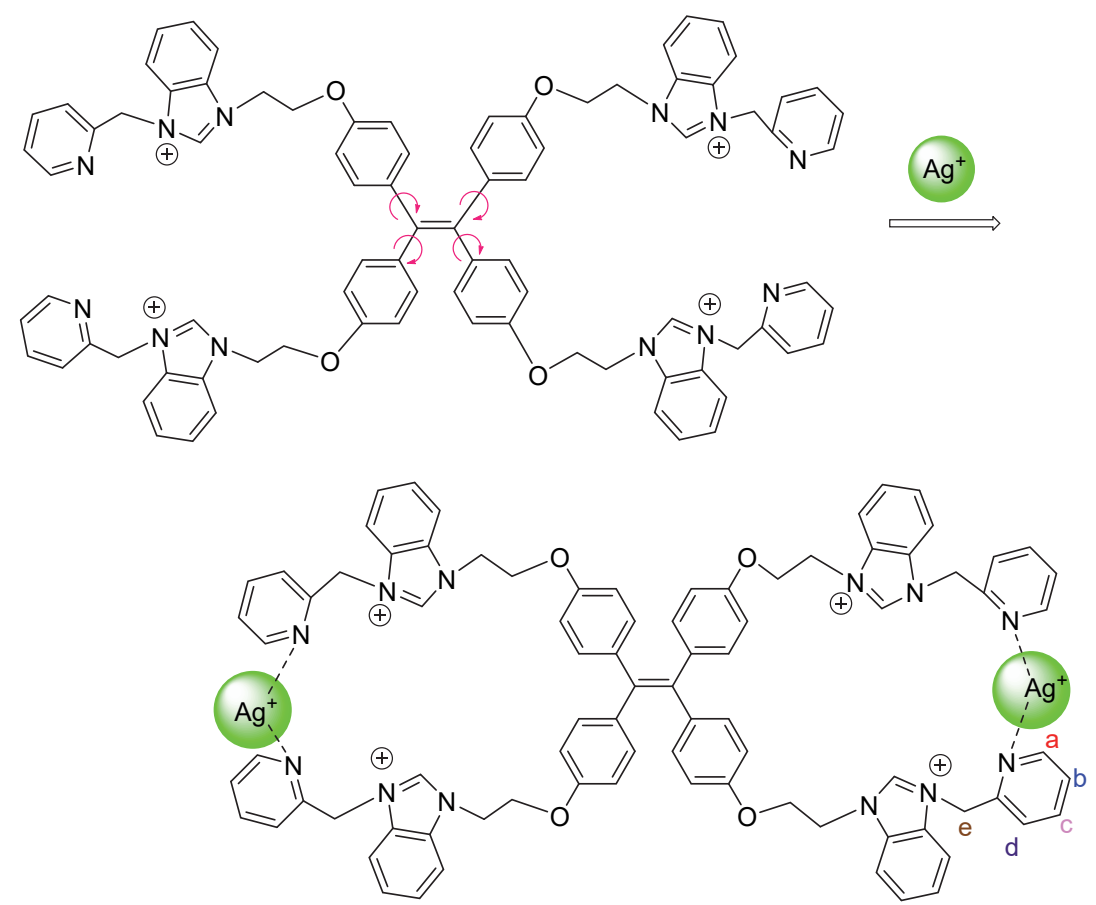

Scheme 3 Intramolecular binding mode of 2 with $\mathrm{Ag}^{+}$ 
course of recognition, compound $\mathbf{1}$ was able to recognize selectively the $\mathrm{H}_{2} \mathrm{PO}_{4}^{-}$via $\mathrm{C}-\mathrm{H} \cdots \mathrm{O}$ hydrogen bonds, whereas compound 2 was able to hold $\mathrm{Ag}^{+}$by the nitrogen atom on pyridine via $\mathrm{N} \cdots \mathrm{Ag}^{+}$interactions. The results indicated that compound $\mathbf{1}$ (or $\mathbf{2}$ ) possessed high sensitivity and selectivity in the detections of $\mathrm{H}_{2} \mathrm{PO}_{4}^{-}$( $\mathrm{or} \mathrm{Ag}^{+}$). Even though the detection limits dropped to $1.5 \times 10^{-8} \mathrm{~mol} / \mathrm{L}$ for 1 (or $1.3 \times 10^{-8} \mathrm{~mol} / \mathrm{L}$ for 2), compound $\mathbf{1}$ (or 2) for the detections of $\mathrm{H}_{2} \mathrm{PO}_{4}^{-}$(or $\mathrm{Ag}^{+}$) was still sensitive.

In compounds 1 (or 2), the remarkable enhancement of fluorescence intensity at $400 \sim 600 \mathrm{~nm}$ upon adding $\mathrm{H}_{2} \mathrm{PO}_{4}^{-}$(or $\mathrm{Ag}^{+}$) was attributed to the aggregation-induced emission (AIE). This phenomenon has been widely reported for tetraphenylethylene derivatives. ${ }^{[45-48]}$ The tetraphenylethene has a structure of propeller-shape due to the rotation of benzene linked on ethene. When $\mathrm{H}_{2} \mathrm{PO}_{4}^{-}$ (or $\mathrm{Ag}^{+}$) was held by $\mathbf{1}$ (or 2), the rotation of benzene was restricted to lead to the aggregation-induced emission enhancement. The binding modes between the host and the guest for $\mathbf{1} \cdot 2 \mathrm{H}_{2} \mathrm{PO}_{4}^{-}$(or $2 \cdot 2 \mathrm{Ag}^{+}$) include mainly three types as shown in Scheme S1: (1) the intramolecular binding mode (I), namely, one host and two guests combine to form a complex; (2) the intermolecular chain-like mode (II), namely, the multiple hosts and multiple guests combine to form a chain-like structure; (3) the intermolecular layered mode (III), namely, multiple hosts and multiple guests combine to form a layered structure. Whether a single host or multiple hosts interacted with the guests, the ratio between host and guest was all $1: 2$, and the fluorescence intensities of complexes are all increased. To obtain more effective and convenient probes for guest, the preparation of new polydentate azolium salts is ongoing.

\section{Experimental section}

\subsection{Basic procedures}

$\mathrm{N}$-Picolyl-benzimidazole was synthesized by the method reported in literatures. ${ }^{[49-50]}$ All operations used Schlenk technology and the solvents were purified according to standard procedures. Analytical reagents for synthesis and analysis didn't need further purification.

The melting point was determined using a Boetius Block device. On the mercury Vx Varian 400 spectrometer recorded $400 \mathrm{MHz}$ or $100 \mathrm{MHz}$ of ${ }^{1} \mathrm{H}$ NMR or ${ }^{13} \mathrm{C} \mathrm{NMR}$ spectrum. For ${ }^{1} \mathrm{H}$ NMR and ${ }^{13} \mathrm{C}$ NMR, the chemical shift $\delta$ was expressed relative to the internal standard TMS. The value of $J$ was expressed in Hz. The Perkin-Elmer 2400C Elemental Analyze was used for the measurement of elemental analysis. The Cary Eclipse fluorescence spectrophotometer was used for the measurement of fluorescence spectra. The JASCO-V570 spectrometer was used for the measurement of UV/vis spectra. The VG ZAB-HS mass spectrometer (VG, UK) was used for the measurement of EI mass spectra. The Bruker Equinox 55 spectrometer (potassium bromide) was used for the measurement of infrared spectra.
4.2 Preparation of 1,1,2,2-tetrakis(4-hydroxyphenyl)ethylene

$\mathrm{TiCl}_{4}(1.4 \mathrm{~mL}, 12.8 \mathrm{mmol})$ was slowly added into the suspension of $\mathrm{Zn}$ powder $(1.760 \mathrm{~g}, 26.9 \mathrm{mmol})$ in dry tetrahydrofuran (THF) $(50 \mathrm{~mL})$ at $0{ }^{\circ} \mathrm{C}$ under nitrogen atmosphere with stirring. After the addition was completed, this mixture was slowly heated to $25{ }^{\circ} \mathrm{C}$, and reacted continually for $2 \mathrm{~h}$. Then 4,4'-dihydroxybenzophenone $(3.000$ g, $14.0 \mathrm{mmol})$ in THF $(50 \mathrm{~mL})$ was added into the above suspension, and this reaction was conducted for another 12 $\mathrm{h}$ under refluxing. This suspension was cooled to room temperature and poured into $10 \% \mathrm{~K}_{2} \mathrm{CO}_{3}$ aqueous solution $(150 \mathrm{~mL})$, and subsequent extraction with ethyl acetate $(20$ $\mathrm{mL} \times 3$ ) was conducted. Ethyl acetate layer was dried on $\mathrm{MgSO}_{4}$. After filtrating and removing ethyl acetate, 1,1,2,2tetrakis(4-hydroxyphenyl)ethylene was obtained as yellow powder with $69 \%$ yield $(1.920 \mathrm{~g})$, and it was purified via recrystallization with acetone $.^{[51-52]} \mathrm{m} . \mathrm{p} .>300{ }^{\circ} \mathrm{C} ;{ }^{1} \mathrm{H} \mathrm{NMR}$ (400 MHz, DMSO- $d_{6}$ ) $\delta: 6.45$ (d, $J=8.5 \mathrm{~Hz}, 8 \mathrm{H}, \mathrm{PhH}$ ), 7.05 (d, $J=8.6 \mathrm{~Hz}, 8 \mathrm{H}, \mathrm{PhH}), 8.93$ (s, 4H, OH).

4.3 Preparation of 1,1,2,2-tetrakis[(2'-bromoethoxyphenyl)]ethylene

An acetonitrile $(30 \mathrm{~mL})$ suspension of 1,1,2,2-tetrakis(4-hydroxyphenyl)ethylene (2.000 g, $5.1 \mathrm{mmol}$ ) and $\mathrm{K}_{2} \mathrm{CO}_{3}$ (7.561 g, $54.7 \mathrm{mmol}$ ) was refluxed with stirring for $2 \mathrm{~h}$, followed by adding 1,2-dibromoethane (12.210 g, 65.0 mmol) to above solution and continually stirring for $3 \mathrm{~d}$. The yellow powder of 1,1,2,2-tetrakis[(2'-bromoethoxyphenyl)] ethylene was obtained with $66 \%$ yield $(2.782 \mathrm{~g})$ after the solvent was removed, and the solid was further purified via recrystallization using 1,4-dioxane/hexane $(V$ : $V=1: 1)$. m.p. $121 \sim 122{ }^{\circ} \mathrm{C} ;{ }^{1} \mathrm{H}$ NMR $(400 \mathrm{MHz}$, DMSO- $\left.d_{6}\right) \delta: 3.76\left(\mathrm{t}, J=10.6 \mathrm{~Hz}, 8 \mathrm{H}, \mathrm{CH}_{2}\right), 4.24(\mathrm{t}, J=9.6$ $\mathrm{Hz}, 8 \mathrm{H}, \mathrm{CH}_{2}$ ), 6.72 (d, $\left.J=8.8 \mathrm{~Hz}, 8 \mathrm{H}, \mathrm{PhH}\right), 6.83$ (d, $J=9.1$ $\mathrm{Hz}, 8 \mathrm{H}, \mathrm{PhH}$ ). Anal. calcd for $\mathrm{C}_{34} \mathrm{H}_{32} \mathrm{O}_{4} \mathrm{Br}_{4}: \mathrm{C} 49.55, \mathrm{H}$ 3.91; found C 49.51, H 3.88.

4.4 Synthesis of 1,1,2,2-tetrakis\{4-[2'-(N-methyl-imidazolium-1-yl)ethoxy]phenyl\}ethylene hexafluorophosphate (1)

1,1,2,2-Tetrakis[(2'-bromoethoxyphenyl)]ethylene $(1.500 \mathrm{~g}, 1.8 \mathrm{mmol})$ and $N$-methyl-imidazole $(1.168 \mathrm{~g}, 14.2$ $\mathrm{mmol})$ were dissolved in acetonitrile $(100 \mathrm{~mL})$, and the mixture was refluxed with stirring for $6 \mathrm{~d}$. After removing solvent by rotary evaporator, a crude product was gotten, and it was further purified via recrystallization with ethyl acetate to give a light yellow power. This light yellow power was dissolved in methanol $(20 \mathrm{~mL})$, and then the methanol solution $(20 \mathrm{~mL})$ of $\mathrm{NH}_{4} \mathrm{PF}_{6}(1.410 \mathrm{~g}, 8.6 \mathrm{mmol})$ was added to above solution with stirring at room temperature for $72 \mathrm{~h}$, and a white solid was gradually formed. After filtration, 1,1,2,2-tetrakis $\{4$-[2'-( $N$-methyl-imidazolium-1yl)ethoxy]phenyl \}ethylene hexafluorophosphate (1) was obtained with $60 \%$ yield $(1.534 \mathrm{~g})$ through washing with a small amount of methanol. m.p. $210 \sim 211{ }^{\circ} \mathrm{C} ;{ }^{1} \mathrm{H}$ NMR $\left(400 \mathrm{MHz}, \mathrm{DMSO}-d_{6}\right) \delta: 3.86\left(\mathrm{~s}, 12 \mathrm{H}, \mathrm{CH}_{3}\right), 4.23(\mathrm{~s}, 8 \mathrm{H}$, $\left.\mathrm{CH}_{2}\right), 4.54\left(\mathrm{~s}, 8 \mathrm{H}, \mathrm{CH}_{2}\right), 6.71(\mathrm{~d}, J=8.0 \mathrm{~Hz}, 8 \mathrm{H}, \mathrm{PhH}), 6.81$ 
(d, J=8.0 Hz, 8H, PhH), 7.32 (s, 8H, PhH), 9.13 (s, 4H, 4-imiH); ${ }^{13} \mathrm{C}$ NMR (100 MHz, DMSO-d $) \delta: 155.9(\mathrm{PhC})$, 138.0 (imi-NCN), $136.9(\mathrm{C}=\mathrm{C}), 136.7(\mathrm{PhC}), 131.9(\mathrm{PhC})$, $123.4(\mathrm{PhC}), 122.7(\mathrm{PhC}), 113.8(\mathrm{PhC}), 65.4\left(\mathrm{OCH}_{2} \mathrm{CH}_{2}\right)$, $48.4\left(\mathrm{NCH}_{2}\right), 35.7\left(\mathrm{CH}_{3}\right)$. Anal. calcd for $\mathrm{C}_{50} \mathrm{H}_{56} \mathrm{~F}_{24} \mathrm{~N}_{8} \mathrm{O}_{4} \mathrm{P}_{4}$ : C 42.50, H 3.99, N 7.93; found C 42.41, H 3.92, N 7.94.

4.5 Preparation of 1,1,2,2-tetrakis $\{[2$ '-( $N$-picolyl-benzimidazolium-1-yl)ethoxyl]phenyl\}ethylene hexafluorophosphate (2)

$N$-Picolyl-benzimidazole $(2.038 \mathrm{~g}, 9.7 \mathrm{mmol})$ and 1,1,2,2-tetrakis[4-(2'-bromoethoxy)phenyl]ethylene (1.000 $\mathrm{g}, 1.2 \mathrm{mmol})$ in acetonitrile $(50 \mathrm{~mL})$ were refluxed for $6 \mathrm{~d}$ to generate a white precipitate. After filtration, a white power was gotten through washing with acetone. This white power was dissolved in $100 \mathrm{~mL}$ of methanol, and then the methanol solution $(20 \mathrm{~mL})$ of $\mathrm{NH}_{4} \mathrm{PF}_{6}(0.963 \mathrm{~g}, 6.0 \mathrm{mmol})$ was added to above solution. After stirring for $72 \mathrm{~h}$ at room temperature, a white solid appeared. 1,1,2,2-Tetrakis $\left\{\left[\left(2^{\prime}-\right.\right.\right.$ ( $N$-picolyl-benzimidazolium-1-yl)ethoxyl]phenyl $\}$ ethylene hexafluorophosphate (2) as a white powder was gotten with $88 \%$ yield $\left(1.020\right.$ g) after filtrating. m.p. $220 \sim 222{ }^{\circ} \mathrm{C} ;{ }^{1} \mathrm{H}$ NMR (400 MHz, DMSO- $\left.d_{6}\right) \delta: 4.33\left(\mathrm{~s}, 8 \mathrm{H}, \mathrm{CH}_{2}\right), 4.95$ (s, $\left.8 \mathrm{H}, \mathrm{CH}_{2}\right), 5.92\left(\mathrm{~s}, 8 \mathrm{H}, \mathrm{CH}_{2}\right), 6.63(\mathrm{~d}, J=8.6 \mathrm{~Hz}, 8 \mathrm{H}, \mathrm{PhH})$, $6.73(\mathrm{~d}, J=8.6 \mathrm{~Hz}, 8 \mathrm{H}, \mathrm{PhH}), 7.32 \sim 7.35(\mathrm{~m}, 1 \mathrm{H}, \mathrm{PhH})$, $7.62 \sim 7.65(\mathrm{~m}, 1 \mathrm{H}, \mathrm{PhH}), 7.64 \sim 7.66(\mathrm{~m}, 2 \mathrm{H}, \mathrm{PhH}), 7.85(\mathrm{t}$, $1 \mathrm{H}, \mathrm{PhH}), 7.93(\mathrm{~d}, J=8.7 \mathrm{~Hz}, 1 \mathrm{H}, \mathrm{PhH}), 8.01(\mathrm{~d}, J=8.7 \mathrm{~Hz}$, $1 \mathrm{H}, \mathrm{PhH}), 8.46$ (d, $J=4.3 \mathrm{~Hz}, 1 \mathrm{H}, \mathrm{PhH}), 9.95$ (s, 4H, 4-bimiH); ${ }^{13} \mathrm{C}$ NMR (100 MHz, DMSO- $\left.d_{6}\right) \delta: 155.9(\mathrm{PhC})$, 152.9 (PyC), 149.4 (PyC), 143.6 (bimi-NCN), 137.4 (PyC), $136.7(\mathrm{C}=\mathrm{C}), 131.8(\mathrm{PyC}), 131.2(\mathrm{PyC}), 131.1(\mathrm{PhC})$, $126.9(\mathrm{PhC}), 126.7(\mathrm{PhC}), 125.5(\mathrm{PhC}), 123.6(\mathrm{PhC}), 122.6$ $(\mathrm{PhC}), 114.1$ (PhC), 114.0 (PhC), 113.7 (PhC), 65.0 $\left(\mathrm{OCH}_{2} \mathrm{CH}_{2}\right), 50.7\left(\mathrm{NCH}_{2} \mathrm{Py}\right), 46.4\left(\mathrm{NCH}_{2}\right)$. Anal. calcd for $\mathrm{C}_{86} \mathrm{H}_{76} \mathrm{~F}_{24} \mathrm{~N}_{12} \mathrm{O}_{4} \mathrm{P}_{4}$ : C 53.75, H 3.98, $\mathrm{N} 8.74$; found $\mathrm{C} 53.71$, $\mathrm{H} 4.01, \mathrm{~N} 8.71$.

\subsection{Fluorescence titrations}

The host stock was prepared at a concentration of $1.0 \times$ $10^{-6} \mathrm{~mol} / \mathrm{L}$ in EtOH/DMSO $(V: V=99: 1)$. The guest's original solution $\left(1.0 \times 10^{-4} \mathrm{~mol} / \mathrm{L}\right)$ was prepared in EtOH/DMSO $(V: V=99: 1)$. The sample solution was prepared by placing $1.0 \mathrm{~mL}$ of host solution and various amounts of guest solution in a $10 \mathrm{~mL}$ of volumetric flask, and then diluting to $10 \mathrm{~mL}$. In the specimen solution, the concentration of the host is $1.0 \times 10^{-6} \mathrm{~mol} / \mathrm{L}$, and the concentration of the guest is from 0 to $11 \times 10^{-6} \mathrm{~mol} / \mathrm{L}$ for 1 (or 0 to $33 \times 10^{-6} \mathrm{~mol} / \mathrm{L}$ for 2 ). After every time of guest was added, the equilibrium time was $8 \sim 10 \mathrm{~min}$, and then fluorescence spectrum was recorded. The fluorescence titration experiment was carried out on a Cary Eclipse fluorescence spectrophotometer with a quartz tube of $1 \mathrm{~cm}$ path-length. The sample solution was excited at $345 \mathrm{~nm}$ with an excitation slit of $10 \mathrm{~nm}$ and an emission slit of $5 \mathrm{~nm}$. In the 345 $650 \mathrm{~nm}$ recorded fluorescence emission spectrum. Origin 8.0 was used for statistical analysis of the data. Ethanol and DMSO of fresh distillation were used in the titration.

\subsection{UV/vis titrations}

$\mathrm{UV} /$ vis titration sample solution was prepared by a method similar to fluorescence titration. In the specimen solution, the concentration of the host is $1.0 \times 10^{-5} \mathrm{~mol} / \mathrm{L}$ for 1 (or $1.0 \times 10^{-6} \mathrm{~mol} / \mathrm{L}$ for 2 ), and the concentration of the guest is $0 \sim 60 \times 10^{-6} \mathrm{~mol} / \mathrm{L}$ for 1 (or $0 \sim 70 \times 10^{-6}$ $\mathrm{mol} / \mathrm{L}$ for 2 ). After every time of guest was added, the equilibrium time was $8 \sim 10 \mathrm{~min}$, and the absorption spectra were measured using the JASCO-V570 spectrometer. The absorption spectra were recorded with a $1 \mathrm{~cm}$ path length quartz cuvette at 25 degree Celsius in the $240 \sim 425 \mathrm{~nm}$ direction. Origin 8.0 was used for statistical analysis of the data.

\subsection{Job's plot}

We used similar methods with fluorescence experiments to prepare the stock solutions. In the measuring solutions, the molar ratios of $c_{\text {Host }} / c_{\text {Guest }}$ were in the ranges of $1: 0 \sim$ $0: 1$, and the total concentration was $1.0 \times 10^{-5} \mathrm{~mol} / \mathrm{L}$ or $1.0 \times 10^{-6} \mathrm{~mol} / \mathrm{L}$. The absorption spectra were measured on the basis of the ways of ultraviolet titrations.

Supporting Information Tables, Figures and ${ }^{1} \mathrm{H}$ NMR and ${ }^{13} \mathrm{C}$ NMR spectra for compounds. The Supporting Information is available free of charge via the Internet at http://sioc-journal.cn/.

\section{References}

[1] Li, J.; Yang, X. P.; Zhang, D.; Liu, Y. X.; Tang, J.; Li, Y.; Zhao, Y. F.; Ye, Y. Sens. Actuators, $B$ 2018, 265, 84.

[2] Yang, X. P.; Wang, Y. S.; Liu, R.; Zhang, Y. R.; Tang, J.; Yang, E. B.; Zhang, D.; Zhao, Y, F.; Ye, Y. Sens. Actuators, B 2019, 288, 217.

[3] Huang, K.; Yue, Y. X.; Jiao, X. J.; Liu, C.; Wang, Q.; He, S.; Zhao, L. C.; Zeng, X. S. Dyes Pigm. 2017, 143, 379.

[4] Jiao, X. J.; Liu, C.; He, S.; Zhao, L. C.; Zeng, X. S. Dyes Pigm. 2019, $160,86$.

[5] Jiang, X. D.; Zhao, J. L.; Li, Q.; Sun, C. L.; Guan, J.; Sun, G. T.; Xiao, L. J. Dyes Pigm. 2016, 125, 136.

[6] Fang, T.; Jiang, X. D.; Sun, C. L.; Li, Q. Sens. Actuators, B 2019, 290, 551.

[7] Qu, W.; Fang, H.; Huang, Q.; Zhang, Y.; Lin, Q.; Yao, H.; Wei, T. Chin. J. Org. Chem. 2019, 39, 1226 (in Chinese). (曲文娟, 房虎, 黄青, 张有明, 林奇, 姚虹, 魏太保, 有机化学, 2019, 39, 1226.)

[8] Li, Y.; Zhao, Y.; Jin, K.; Liu, J.; Zhou, X.; Yang, K. Chin. J. Org. Chem. 2019, 39, 1013 (in Chinese). (李英俊, 赵月, 靳焜, 刘季红, 周晓霞, 杨凯栋, 有机化学, 2019, 39, 1013.)

[9] Zhu, Y.; Wang, Z.; Yang, J.; Xu, X.; Wang, S. Chin. J. Org. Chem. 2019, 39, 427 (in Chinese).

(朱阳明, 王忠龙, 杨剑, 徐徐, 王石发, 有机化学, 2019, 39, 427.)

[10] Li, Y.; Zhang, N.; Liu, J.; Jin, K.; Wang, S. Chin. J. Org. Chem. 2018, 38, 3026 (in Chinese).

(李英俊, 张楠, 刘季红, 靳焜, 王思远, 有机化学, 2018, 38, 3026.)

[11] Gong, Z. L.; Zhong, Y. W. Inorg. Chem. 2016, 55, 10143.

[12] Jose, D. A.; Mishra, S.; Ghosh, A.; Shrivastav, A.; Mishra, S. K.; Das, A. Org. Lett. 2007, 9, 1979.

[13] Kim, H. N.; Moon, J. H.; Kim, S. K.; Kwon, J. Y.; Jang, Y. J.; Lee, J. Y.; Yoon, J. Y. J. Org. Chem. 2011, 76, 3805.

[14] Lopéz-Martínez, L. M.; García-Elías, J.; Ochoa-Terán, A.; Ortega, 
H. S.; Ochoa-Lara, K.; Montaño-Medina, C. U.; Yatsimirsky, A. K.; Ramírez, J. Z.; Labastida-Galván, V.; Ordoñez, M. Tetrahedron 2020, 76, 130815 .

[15] Banerjee, M.; Ta, S.; Ghosh, M.; Ghosh, A.; Das, D. ACS Omega 2019, 4, 10877.

[16] Lukasik, N.; Chojnacki, J.; Luboch, E.; Okuniewski, A.; Wagner-Wysiecka, E. J. Photochem. Photobiol., A 2020, 390, 112307.

[17] Naskar, K.; Bhanja, A. K.; Paul, S.; Pal, K.; Sinha, C. Cryst. Growth Des. 2020, 20, 6453.

[18] Sabater, P.; Zapata, F.; Bastida, A.; Caballero, A. Org. Biomol. Chem. 2020, $18,3858$.

[19] Ganjali, M. R.; Norouzi, P.; Alizadeh, T.; Adib, M. J. Braz. Chem. Soc. 2006, 17, 1217.

[20] Zhang, X. B.; Han, Z. X.; Fang, Z. H.; Shen, G. L.; Yu, R. Q. Anal. Chim. Acta 2006, 562, 210.

[21] Peng, H. Q.; Brooks, B. W.; Chan, R.; Chyan, O.; Point, T. W. L. Chemosphere 2002, 46, 1141.

[22] Wan, A. T.; Conyers, R. A.; Coombs, C. J.; Masterton, J. P. Clin. Chem. 1991, 37, 1683.

[23] Liu, C.; Huang, S. S.; Yao, H. R.; He, S.; Lu, Y.; Zhao, L. C.; Zeng, X. S. RSC Adv. 2014, 4, 16109.

[24] Yu, C.; Zhang, J.; Ding, M.; Chen, L. Anal. Methods 2012, 4, 342.

[25] Lou, T.; Chen, Z;; Wang, Y.; Chen, L. ACS Appl. Mater. Interfaces 2011, 3, 1568 .

[26] Chen, L.; Zhao, Q.; Zhang, X. Y.; Tao, G. H. Chin. Chem. Lett. 2014, 25, 261 .

[27] Ratte, H. T. Environ. Toxicol. Chem. 1999, 18, 89.

[28] Zhang, B.; Sun, J.; Bi, C.; Yin, G.; Pu, L.; Shi, Y.; Sheng, L. New J. Chem. 2011, 35, 849 .

[29] Zhang, W.; Luo, Y.; Zhou, Y.; Liu, M.; Xu, W. T.; Bian, B.; Tao, Z.; Xiao, X. Dyes Pigm. 2020, 176, 108235.

[30] Wang, Y. J.; Liu, J. G.; Tan, H. Y.; Yan, J. W.; Zhang, L. RSC Adv. 2017, 7, 55567.

[31] Zhang, Y. W.; Ye, A. Y.; Yao, Y. W.; Yao, C. Sensors 2019, 19, 247.

[32] Kong, D. D.; Weng, T. Q.; He, W. X.; Liu, B.; Jin, S.; Hao, X.; Liu, S. H. J. Organomet. Chem. 2013, 727, 19.

[33] Liu, Q. X.; Zhao, X. J.; Hu, Z. L.; Zhao, Z. X.; Wang, H. Sci. Reports 2017, 7, 7534.

[34] Liu, K.; Zhao, X. J.; Liu, Q. X.; Huo, J. Z.; Li, Z. C.; Wang, X. X. Sens. Actuators, B 2017, 239, 883.
[35] Su, J. X.; Wang, X. T.; Chang, J.; Wu, G. Y.; Wang, H. M.; Yao, H.; Lin, Q.; Zhang, Y. M.; Wei, T. B. Spectrochim. Acta, Part A 2017, $182,67$.

[36] Qu, W. J.; Yan, G. T.; Ma, X. L.; Wei, T. B.; Lin, Q.; Yao, H.; Zhang, Y. M. Sens. Actuators, B 2017, 242, 849.

[37] Arumugaperumal, R.; Srinivasadesikan, V.; Raju, M. V. R.; Lin, M. C.; Shukla, T.; Singh, R.; Lin, H. C. ACS Appl. Mater. Interfaces 2015, 7, 26491.

[38] Suganyaa, S.; Velmathia, S.; Venkatesan, P.; Wu, S. P.; Boobalan, M. S. Inorg. Chem. Front. 2015, 2, 649

[39] Liu, Q. C.; Liu, C.; Chang, L. F.; He, S.; Lu, Y.; Zeng, X. S. RSC Adv. 2014, 4, 14361

[40] Wang, C. C.; Zhang, D.; Huang, X. Y.; Ding, P. G.; Wang, Z. J.; Zhao, Y. F.; Ye, Y. Sens. Actuators, B 2014, 198, 33.

[41] Prabhu, J.; Velmurugan, K.; Zhang, Q.; Radhakrishnan, S.; Tang, L.; Nandhakumar, R. J. Photochem. Photobiol., A 2017, 337, 6.

[42] Li, L. Q.; Gao, L. J. Spectrochim. Acta, Part A 2016, 152, 426.

[43] Ghosh, A.; Adhikari, S.; Ta, S.; Banik, A.; Dangar, T. K.; Mukherjee, S. K.; Matalobos, J. S.; Brandão, P.; Félix, V.; Das, D. Dalton Trans. 2016, 45, 19491.

[44] Velmurugan, K.; Suresh, S.; Santhoshkumar, S.; Saranyab, M.; Nandhakumara, R. Luminescence 2016, 31, 722.

[45] Wang, J. G.; Gu, X. G.; Zhang, P. F.; Huang, X. B.; Zheng, X. Y.; Chen, M.; Feng, H. T.; Ryan, T. K.; Jacky, W. Y.; Tang, B. Z. J. Am. Chem. Soc. 2017, 139, 16974.

[46] Liu, L.; Zhang, G. X.; Xiang, J. F.; Zhang, D. Q.; Zhu, D. B. Org. Lett. 2008, 10, 4581 .

[47] Chen, Z.; Zhang, J.; Song, M.; Yin, J.; Yu, G. A.; Liu, S. H. Chem. Commun. 2015, 51, 326.

[48] Chen, Z.; Wu, D.; Han, X.; Liang, J.; Yin, J.; Yu, G. A.; Liu, S. H. Chem. Commun. 2014, 50, 11033.

[49] Jan, C. B. Han, V. H. Organometallics 2014, 33, 5845.

[50] Gu, X. X.; Zhu, X. C.; Wei, Y.; Wang, S. W.; Zhou, S. L.; Zhang, G. C.; Mu, X. L. Organometallics 2014, 33, 2372.

[51] Tomohisa K.; Atsushi K.; Kyosuke N.; Kenichi H. Biochem. Biophys. Res. Commun. 2010, 394, 200.

[52] Guan, X. L.; Zhang, D. H.; Meng, L.; Zhang, Y.; Jia, T. M.; Jin, Q. J.; Wei, Q. B.; Lu, D. D.; Ma, H. C. Ind. Eng. Chem. Res. 2017, 56, 680. 